\title{
Activation of the atypical NF-kB pathway induced by ionizing radiation is not affected by the p53 status
}

\author{
Gracjana Zając1,2, Marek Rusin1, Barbara Łasut-Szyszka1', Krzysztof Puszynski² and \\ Piotr Widłak'® \\ IMaria Sklodowska-Curie National Research Institute of Oncology, Gliwice Branch, Gliwice, Poland; 2Silesian University of Technologies, Gliwice, \\ Poland
}

DNA double-strand breaks induced by ionizing radiation can activate the atypical NF-KB pathway via ATMmediated phosphorylation of NEMO/IKK $\gamma$. We aimed to determine whether the status of p53 influenced the activation of this particular NF-KB pathway. The NF-KB signaling was activated either by irradiation with a single 8 Gy dose or by TNFa cytokine in p53-proficient and p53-deficient variants of HCT116, RKO, and U2-OS human cancer cell lines. To assess pathway activation the kinetics of phosphorylation (Ser32) and proteolytic degradation of IKBa inhibitor and phosphorylation (Ser536) of RelA(p65) NF-KB subunit were analyzed. Though activation of the radiation-induced atypical pathway was delayed and weakened when compared to the cytokine-induced canonical pathway, no significant differences were noted between p53-proficient and p53-deficient variants, which indicated that activation of both NF-KB pathways was not affected by the p53 status. In marked contrast, the presence of p53 significantly affected downstream effects of NF-KB activation, i.e. transcription of NF-KBdependent genes. However, different patterns of such interference were observed, which indicated gene-specific and cell-specific mechanisms of interactions between $\mathrm{NF}-\mathrm{KB}$ and p53 at the transcription regulation level.

Keywords: radiation response; NF-KB pathway; cellular signaling; Received: 05 October, 2021; revised: 03 December, 2021; accepted: 06 December, 2021; available on-line: 07 February, 2022

$凶$ e-mail: Piotr.Widlak@io.gliwice.pl

Acknowledgements of Financial Support: This research was funded by the National Science Centre, grant number 2016/23/B/ ST6/03455, and 2019/35/O/NZ5/02600.

Abbreviations: ATM, Ataxia-telangiectasia mutated protein; DDR, DNA damage response; DSB, double-strand breaks; gRNA, guide RNA; IKK, IKB kinase; IR, ionizing radiation; qRT-PCR, quantitative Reverse Transcription-Polymerase Chain Reaction; TNFa, Tumor Necrosis Factor alfa

\section{INTRODUCTION}

$\mathrm{NF}-x \mathrm{~B}$ is a transcription factor regulating cell response to different types of stimuli, whose primary function is regulation of the immune response and inflammation. However, the $x \mathrm{~B}$ responsive element was found in regulatory regions of several hundred genes, therefore this factor could also regulate genes involved in many other processes, including apoptosis, cell cycle, angiogenesis, and metastasis. Hence, up-regulation of the NF- $x \mathrm{~B}$ pathway is frequently observed in cancer cells which may contribute to their resistance to the anticancer treatment Vallabhapurapu \& Karin, 2009; Hayden \& Ghosh, 2012; Perkins, 2012; Taniguchi, \& Karin, 2018). NF- $x$ B tran- scription factors are dimers formed by members of the multigene $\mathrm{NF} \varkappa \mathrm{B} / \mathrm{Rel}$ family which in humans includes five proteins. In general, in resting cells, NF- $x \mathrm{~B}$ dimers are sequestered in the cytoplasm by association with inhibitory proteins called I $x$ B. Pro-inflammatory extracellular signals or cellular stress can induce activation of $\mathrm{I} \chi \mathrm{B}$ kinase $(\mathrm{IKK})$, which in turn phosphorylates $\mathrm{I} \varkappa \mathrm{B}$ protein that allows freeing and translocation of $\mathrm{NF}-x \mathrm{~B}$ to the nucleus and its binding to the $x \mathrm{~B} \mathrm{DNA}$ regulatory elements (Perkins, 2012; Hoesel \& Schmid, 2013). The RelA(p65)/ $\mathrm{NF}-x \mathrm{~B} 1(\mathrm{p} 50)$ heterodimer is the most abundant NF- $x \mathrm{~B}$ form which is involved in the so-called "classical" or "canonical" NF- $x \mathrm{~B}$ pathway. This pathway is primarily activated by pro-inflammatory stimulation (e.g. by the TNF $\alpha$ cytokine) and involves IKK $\beta$-catalyzed phosphorylation and subsequent proteolysis of $\mathrm{I} \varkappa \mathrm{B} \alpha$ inhibitory protein. Moreover, an alternative ("non-canonical") pathway exists, which involves IKK $\alpha$-mediated phosphorylation and processing of the NF- $x \mathrm{~B} 2(\mathrm{p} 100)$ form, leading to induction of p52-containing NF- $x \mathrm{~B}$ complexes (Sun, 2011). Additionally, several "atypical" pathways were also described, including radiation inducible mechanisms of NF- $x$ B activation (Wu \& Miyamoto, 2007; Habraken \& Piette, 2006; Kriete \& Mayo, 2009). It is well documented that the DNA double-strand break, a critical form of damage induced by ionizing radiation (IR), can activate $\mathrm{NF}-x \mathrm{~B}$ signaling via ATM-dependent mechanisms (Brach et al., 1991; Li \& Karin, 1998). There are multiple pathways of ATM-mediated activation of IKK via NEMO/ $\mathrm{IKK} \gamma$, which leads to phosphorylation and proteolytic degradation of $\mathrm{I} x \mathrm{~B} \alpha$ with subsequent nuclear translocation of RelA(p65)/NF- $x$ B1 (p50) heterodimer (Huang et al., 2003; Janssens et al., 2005; Wu et al., 2006; Janssens \& Tschopp, 2006). More recently, a non-canonical mechanism of activation of the DNA sensing adaptor STING induced by DNA breaks, which depends on IFI16 and ATM, and leads to activation of the innate immune response via activation of $\mathrm{NF}-x \mathrm{~B}$, was also noted (Dunphy et al. 2018).

Among the major factors involved in cellular response to ionizing radiation is the $\mathrm{p} 53$ protein, a transcription factor encoded by the TP53 gene. The main function of p53 is regulation of genes involved in response to DNA damage, including genes involved in the cell cycle arrest (enabling DNA repair) or apoptosis (enabling removal of cells if DNA damage exceeds the "repairable" threshold). Moreover, genes targeted by p53 are also involved in cell senescence, angiogenesis, metastasis, and innate immunity (Levine \& Oren, 2009; Blagih et al., 2020). The major signal transduction pathways involved in cellular stress response do not function separately, and the final response usually depends on the interaction between dif- 
ferent pathways. Hence, it is important to note that different mechanisms of crosstalk between the NF-xB and p53 pathways exist (Carrà et al., 2020). NF- $x \mathrm{~B}$ can regulate transcription of genes coding for $\mathrm{p} 53$ and its regulator M/HDM2 (Tergaonkar et al., 2002). On the other hand, products of p53-regulated genes can be involved in phosphorylation and dephosphorylation of NF- $x \mathrm{~B}$ (Bohuslav et al., 2004; Chew et al., 2009). Furthermore, the p300/CBP complex (with a histone acetyltransferase activity) is a transcription co-activator essential for expression of genes activated by both p53 and NF- $x \mathrm{~B}$, and both transcription factors compete for binding to it (Webster \& Perkins, 1999; Huang et al., 2007). Moreover, several genes co-regulated by both transcription factors were described (Szołtysek et al., 2018). Interestingly, however, even though p53 is the critical factor involved in numerous aspects of cellular response to ionizing radiation, its role in regulation of the radiation-activated atypical NF- $x \mathrm{~B}$ pathway is not well understood. Hence, we aimed here to determine whether the p53 status influenced activation of this particular NF-xB pathway.

\section{MATERIALS AND METHODS}

\section{Experimental model}

Experiments were performed using established HCT116 and RKO colon carcinoma and U2-OS osteosarcoma cell lines, with two variants each: p53-proficient and p53-deficient. The HCT116 variant, depleted of the TP53 gene due to a bi-allelic knock-out (Bunz et al., 1998), was a generous gift from Dr. B. Vogelstein. The RKO variant, stably transfected with the human papillomavirus E6 protein gene (Kessis et al., 1993), was a generous gift from Dr. M.B. Kastan. The U2-OS variant, depleted of p53, was generated by TP53 mutation using CRISPR Double Nickase Plasmid system (Santa Cruz Biotechnology). Cells were transfected with a pair of plasmids, either TP53-targeting (sc-416469-NIC) or control (sc-437281). Each pair of plasmids encodes modified Cas9 nuclease and target-specific guide RNA (gRNA) (each gRNA targets a sequence on a complementary DNA strand). Following transfection, Cas9 guided by gRNAs generated a double-strand break in a target site, which was repaired in an error-prone fashion generating either frameshift mutations or amino acid deletions. Cells cultured in an antibiotic-free medium were transfected with the plasmid, 72 hrs after the start of transfection puromycin was added to the medium, then the selection lasted for 72 hours (to eliminate cells that were not transfected). To select p53-knockout clones, cells were counted and seeded into the round-bottom 96-well plate at the calculated density of 0.3 cells per well. After 10-14 days of culture, cell populations from individual wells were transferred to larger culture dishes, expanded, and tested for p53 expression by Western blotting. RKO and U2-OS cells were grown in DMEM/F12 medium (Biowest), while HCT116 cells were grown in McCoy's 5A (Biowest), with a final concentration of $10 \%$ FBS (Gibco), and gentamicin $(40 \mathrm{mg} / \mathrm{ml}, \mathrm{Krka})$, at $37^{\circ} \mathrm{C}$ in a humidified $5 \% \mathrm{CO}_{2}$ atmosphere. The cells were inoculated 48 hours before treatment and 20 hours before treatment the culture media were changed. Cells were irradiated with a single dose of $8 \mathrm{~Gy}$ at a $1 \mathrm{~Gy} / \mathrm{min}$ dose rate using $6 \mathrm{MeV}$ photons and a linear accelerator (True Beam, Varian) or incubated with TNF $\alpha$ cytokine (20 ng/ $\mathrm{ml}$; Peprotech). Cells were harvested 5, 15, 30, 60, and 120 minutes after irradiation or incubation with $\mathrm{TNF} \alpha$, then washed with PBS, frozen on dry ice, and stored at $-80^{\circ} \mathrm{C}$. For gene expression analysis, the cells were harvested 4 hours after irradiation or incubation with $\mathrm{TNF} \alpha$ and suspended in TRIzol (A\&A Biotechnology).

\section{Western blot analysis of proteins}

Lysis of cells and Western blot procedure was performed as described in detail by Zajkowicz and others (Zajkowicz et al., 2015). Briefly, to prepare whole-cell lysates, cell pellets were suspended in the IP buffer (composed of $50 \mathrm{mM}$ Tris-HCl, $\mathrm{pH}$ 8.0, $120 \mathrm{mM} \mathrm{NaCl}, 0.5 \% \mathrm{NP}-40$ and supplemented with a protease and phosphatase inhibitors cocktail), incubated on ice for $20 \mathrm{~min}$, and centrifuged $\left(14000 \mathrm{rpm}, 4^{\circ} \mathrm{C}\right.$, $20 \mathrm{~min})$. Two volumes of lysate were mixed with one volume of Laemmli buffer (150 mM Tris ( $\mathrm{pH}$ 6.8), $6 \%$ SDS, 30\% glycerol, $0.01 \%$ bromophenol blue, $7.5 \%$ $\beta$-mercaptoethanol), then heat-denatured $\left(95^{\circ} \mathrm{C}, 5 \mathrm{~min}\right)$, chilled on ice and stored at $-70^{\circ} \mathrm{C}$. Equal amounts of protein lysates $(30 \mu \mathrm{g})$ were separated by SDS-PAGE on $8 \%$ or $12 \%$ gels and electrotransferred onto PVDF membranes. The membranes were blocked for 1 hour at RT in blocking buffer (5\% nonfat milk in PBS with $0.1 \%$ Tween-20), then incubated overnight at $4^{\circ} \mathrm{C}$ with the following primary antibodies: anti-phospho-Ser536-p65 (Cell Signalling Technology, \#3031), anti-phosphoSer32-I $x \mathrm{~B} \alpha$ (Cell Signalling Technology, \#2859), antiphospho-Ser15-p53 (Cell Signalling Technology \#9284), anty-phospho-Thr68-Chk2 (Cell Signalling Technology, \#2661), anti-IxB $\alpha$ (Cell Signalling Technology, \#9242), anti-phospho-Ser1981-ATM (Cell Signalling Technology, \#5883), anti-p53 (Santa Cruz Biotechnology, DO1), and anti-HSC70 (Santa Cruz Biotechnology, B-6). Membranes for anti-phospho-ATM were washed 3 times for 5 min with PBS-Tween and incubated with the primary antibody in 5\% BSA. HRP-conjugated secondary antibodies were detected by chemiluminescence (SuperSignal West Pico, Thermo Scientific).

\section{Gene expression analysis}

Total RNA was isolated and digested with DNAse using Total RNA Zol-Out ${ }^{\text {TM }}$ D kit (A\&A Biotechnology). cDNA synthesis was performed with Random Hexamers using M-MLV Reverse Transcriptase (200 U/ $\mu \mathrm{L}$, Thermo Scientific), $1 \mu \mathrm{g}$ of total RNA was used as a template. The transcript levels of selected genes were analyzed by qRT-PCR (CFX96, BioRad) with application of the SYBR Green C dye (M1, A\&A Biotechnology). The sequences of primers and PCR conditions were described in detail by Janus and others (Janus et al., 2018). All reactions were carried out in triplicate, and expression levels were normalized according to the GAPDH and HNRNPK housekeeping genes. Changes in expression of analyzed genes were addressed as a fold-change against an untreated control. The set of delta-Cq replicates $(\mathrm{Cq}$ values for each sample normalized against the geometric mean of the reference genes) was used to assess the significance of differences by the Student's $t$-test; $p<0.05$ was selected as the significance threshold.

\section{RESULTS}

To analyze the influence of $\mathrm{p} 53$ protein status on activation of the $\mathrm{NF}-x \mathrm{~B}$ pathway, three different cell models were included. HCT116 colon cancer cells were depleted of p53 due to a bi-allelic knock-out of the TP53 gene (Bunz et al., 1998) (original HCT116 cells were used as a 

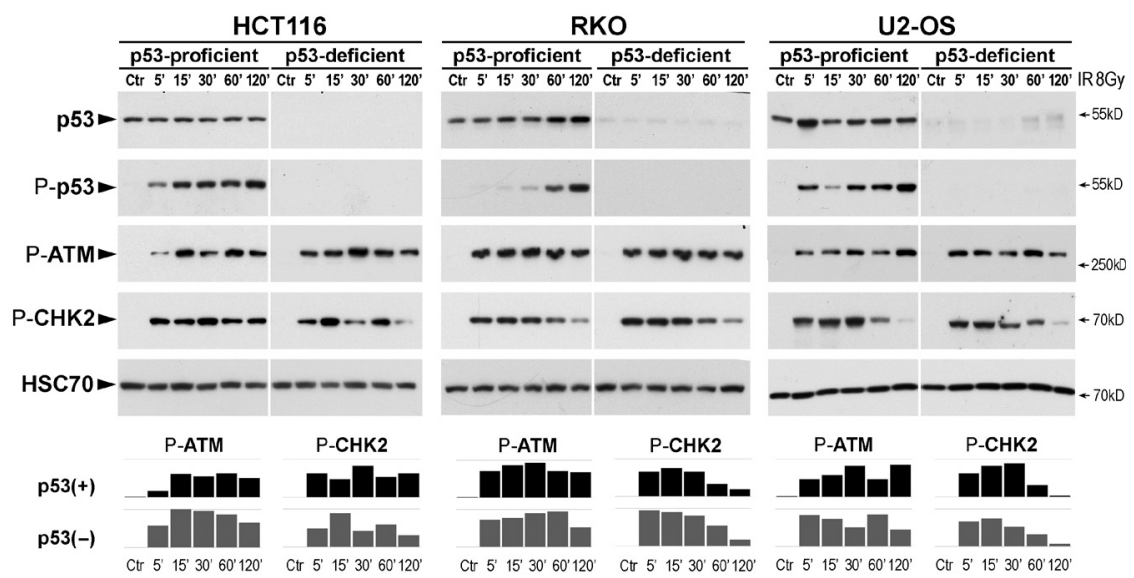

Figure 1. Activation of response to ionizing radiation in cells with different $\mathrm{p} 53$ statuses.

The level of phosphorylated forms of p53 (Ser15), ATM (Ser1981), and CHK2 (Thr68) was analyzed by Western blot, 5 to 120 minutes after irradiation with $8 \mathrm{~Gy}$ in p53-proficient and p53-deficient HCT116, RKO, and U2-OS cells. Positions of relevant molecular weight markers are shown with arrows; HSC70 was used as a loading control; p53-proficient and p53-deficient cells were analyzed in the same experiment serving as the anti-p53 and anti-P-p53 antibodies' positive control. The bars represent the levels of analyzed proteins determined by densitometry of representative gels and normalized to HSC70.

p53-proficient variant). RKO colon cancer cells were depleted of p53 due to co-expression of the human papillomavirus E6 protein gene that binds to p53 and stimulates its proteasomal degradation (Kessis et al., 1993) (cells stably transfected with empty vector were used as a p53-proficient variant). U2-OS osteosarcoma cells were depleted of p53 due to CRISPR-mediated frameshift mutation in the $\mathrm{N}$-terminal part of $\mathrm{p} 53$ followed by selection of clones that do not produce the p53 protein (cells processed with a non-targeting scrambled gRNA were used as a p53-proficient variant). Depletion of p53 protein in all three cell lines was confirmed by Western blot (Fig. 1). Radiation response induced by a single 8 Gy dose was analyzed in p53-proficient and p53-deficient cells at time points ranging between 5 and 120 minutes after irradiation. In all cell lines, irrespective of the p53 status, activation of the ATM kinase (activating phosphorylation of Ser1981) was observed 5 minutes after irradiation, which was accompanied by phosphorylation of the CHK2 kinase (Thr68), i.e., the primary target of the ATM kinase. Hence, we concluded that IR-induced activation of the ATM kinase was independent of the p53 status in the included cell models. Moreover, activating phosphorylation of p53 at Ser15, which is another ATM target (Banin et al., 1998), was observed in p53-proficient variants (it gradually increased starting at 5 minutes after irradiation) (Fig. 1).

Cell variants characterized above were used to analyze the influence of $\mathrm{p} 53$ protein status on activation of the canonical NF- $x \mathrm{~B}$ pathway induced by $\mathrm{TNF} \alpha$ cytokine and the atypical ATM-dependent NF- $x \mathrm{~B}$ pathway induced by a high dose of IR. To characterize this activation, kinetics of the IKK-mediated phosphorylation of $\mathrm{I} x \mathrm{~B} \alpha$ at Ser32, which is a common event in both NF$x \mathrm{~B}$ pathways, were analyzed between 5 and 120 minutes after stimulation. Moreover, activating phosphorylation of p65/RelA NF- $x$ B subunit at Ser536 was analyzed at the same time points (Fig. 2). Strong phosphorylation of $\mathrm{I} \varkappa \mathrm{B} \alpha$ was observed after 5 minutes (HCT116 and $\mathrm{U} 2-\mathrm{OS}$ ) or 15 minutes (RKO) of cytokine stimulation, which was followed by a marked reduction in the total $\mathrm{I} \varkappa \mathrm{B} \alpha$ level after approximately 30 minutes of stimulation (the later increase in $\mathrm{I} \alpha \mathrm{B} \alpha$ level resulted from its de novo synthesis due to $\mathrm{NF}-x \mathrm{~B}$-dependent activation of the NFKBIA gene). Moreover, strong phosphorylation of p65/RelA was also observed after 5-15 minutes of

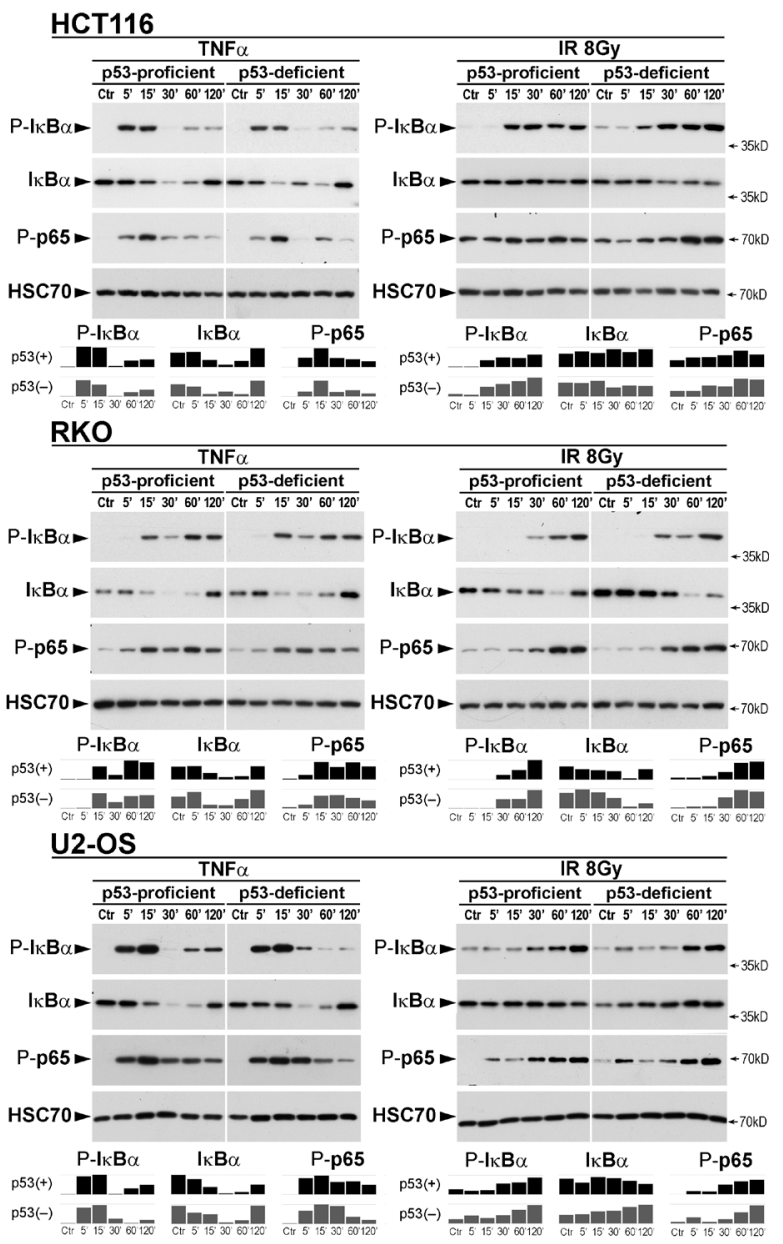

Figure 2. Activation of the NF-KB pathway in cells with different p53 statuses.

The level of the phosphorylated form of ІкBa (Ser32), total IKBa, and phosphorylated form of p65 (Ser536) was analyzed by Western blot, after 5 to 120 minute incubation with TNFa or irradiation with 8 Gy in p53-proficient and p53-deficient HCT116, RKO, and U2-OS cells. Positions of relevant molecular weight markers are shown with arrows; HSC70 was used as a loading control. The bars represent the levels of analyzed proteins determined by densitometry of representative gels and normalized to HSC70. 
cytokine stimulation. Although some differences in the kinetics of $\mathrm{I} \alpha \mathrm{B} \alpha$ phosphorylation/degradation and $\mathrm{p} 65 /$ RelA phosphorylation were detected among the three analyzed cell lines, both p53-proficient and p53-deficient variants of each cell line responded to stimulation with $\mathrm{TNF} \alpha$ cytokine in the same way (Fig. 2). Hence, we concluded that activation of the canonical NF- $x \mathrm{~B}$ pathway was not affected by the p53 status.

Activation of the NF- $x \mathrm{~B}$ pathway in irradiated cells was markedly delayed when compared to cells stimulated with the $\mathrm{TNF} \alpha$ cytokine: phosphorylation of $\mathrm{I} x \mathrm{~B} \alpha$ started 15-30 minutes after irradiation and lasted up to 120 minutes after irradiation. Moreover, a significantly reduced level of the total $\mathrm{I} \varkappa \mathrm{B} \alpha$ was noted only in the RKO cells (60 minutes after irradiation). Similarly, a delay in phosphorylation of p65/RelA was noted - a high level of Ser536-P form was observed 60-120 minutes after irradiation. And again, though some differences in the kinetics of radiation-induced $\mathrm{I} x \mathrm{~B} \alpha$ and $\mathrm{p} 65 / \mathrm{RelA}$ phosphorylation were detected among the three analyzed cell lines, both p53-proficient and p53-deficient variants of each cell line responded similarly to irradiation
(Fig. 2). Hence, we concluded that though activation of the IR-induced atypical NF- $x \mathrm{~B}$ pathway was weaker and delayed when compared to the canonical cytokineinduced pathway, it was not affected by the p53 status.

We also analyzed expression of the NF- $x \mathrm{~B}$-dependent genes in p53-proficient and p53-deficient cells stimulated with the TNF $\alpha$ cytokine or irradiated with a single 8 Gy dose. Five classical NF- $x \mathrm{~B}$ targets were selected (CXCL8, TNFAIP3, NFKB2, BIRC3, and PLAU), as well as the $R R A D$ gene, which was previously described as transcriptionally co-activated by $\mathrm{p} 53$ and $\mathrm{NF}-x \mathrm{~B}$ (Szoltysek et al., 2018). The expression level of these genes was analyzed by qRT-PCR after 4 hours of stimulation to better visualize effects induced by irradiation (according to a previous report IR-induced expression of $\mathrm{NF}-x \mathrm{~B}$-dependent genes is generally weaker and delayed when compared to their cytokine-induced expression (Janus et al. 2018)). Though effects of cytokine stimulation were generally stronger than effects of irradiation, very different expression patterns were observed for different genes and cell lines. For example, in p53-proficient HCT116 cells expression was usually lower, while

\section{HCT116}

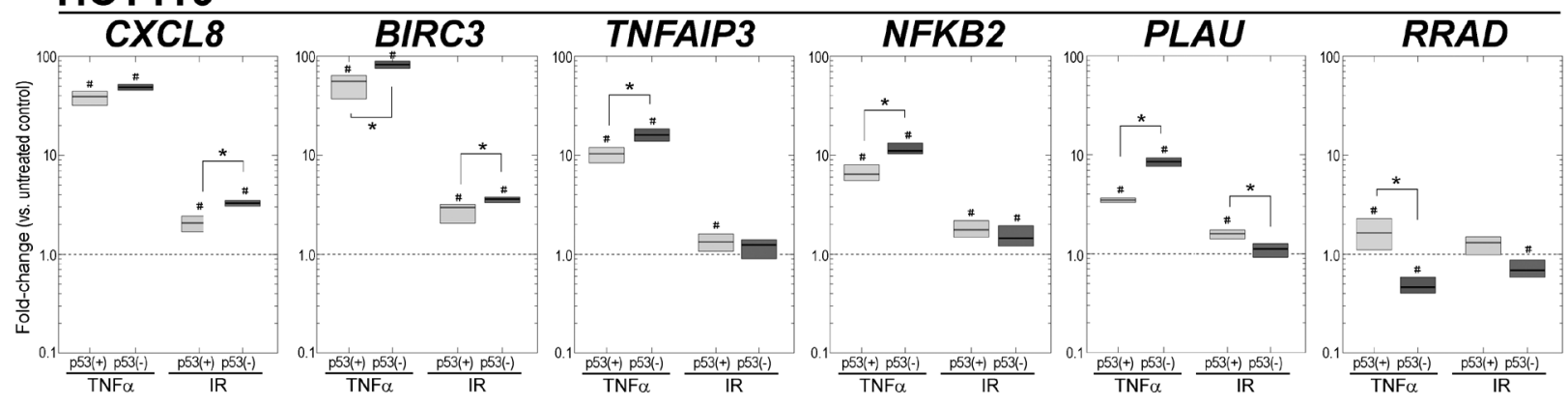

RKO

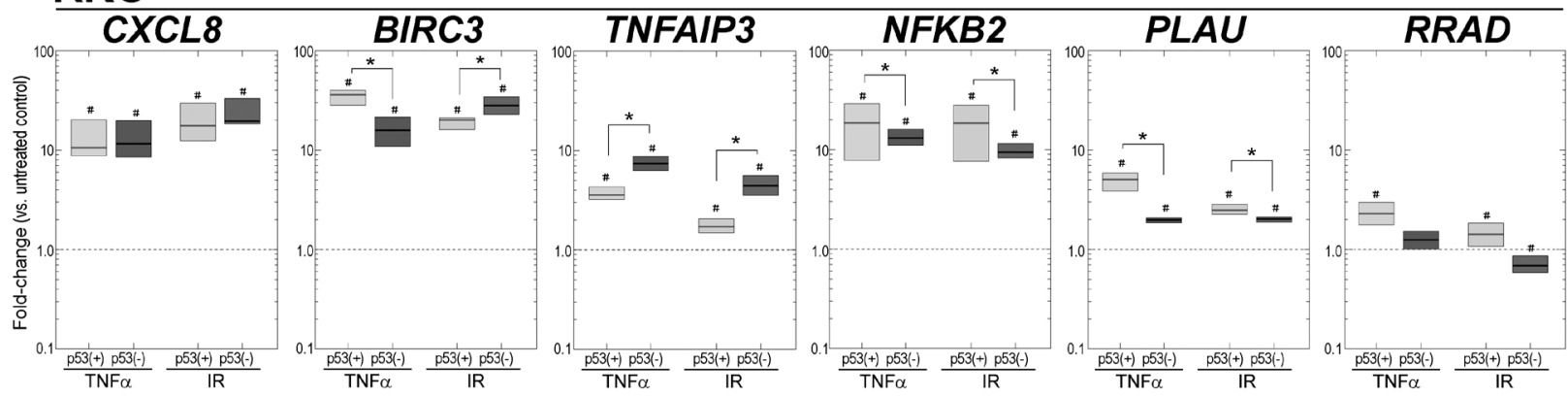

U2-OS

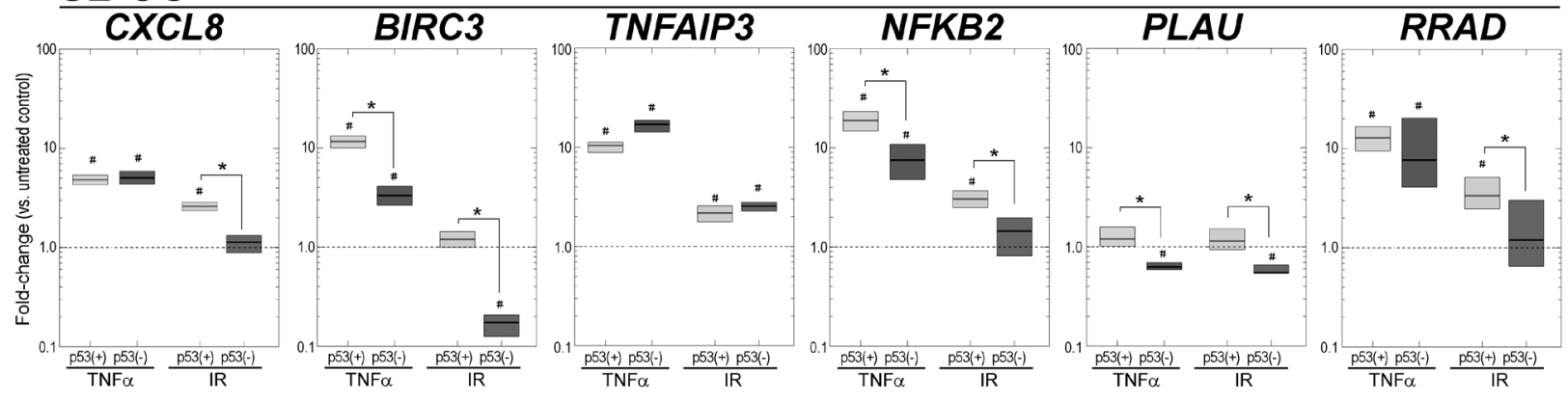

Figure 3. Expression of NF-кB-dependent genes induced by the TNFa cytokine or 8 Gy irradiation in cells with different p53 statuses. The level of mRNA transcripts was analyzed by qRT-PCR after 4 hours of cytokine stimulation (TNFa) or 4 hours after irradiation (IR) in p53-proficient (+) and p53-deficient (-) HCT116, RKO, and U2-OS cells. Significance of changes against untreated controls (fold-change, logarithmic scale) is marked with hashtags $(p<0.05)$, significance of differences between cells with different p53 statuses is marked with asterisks $(p<0.05)$. 
in p53-proficient U2-OS cells expression was usually higher than in the corresponding p53-deficient variants, which putatively reflected gene-specific and cell type-specific differences in transcriptional regulation. Only in the case of the $R R A D$ gene, which is transcriptionally coactivated by $\mathrm{NF}-x \mathrm{~B}$ and $\mathrm{p} 53$, expression was constantly higher in all p53-proficient cell variants (Fig. 3).

\section{DISCUSSION}

Atypical NF- $x \mathrm{~B}$ pathways that are activated in the non-receptor mode by different factors other than inflammatory signals include an ATM-dependent mechanism activated by DNA double-strand breaks (Janssens \& Tschopp, 2006; Habraken \& Piette, 2006; Hellweg, 2015). Though upstream activation mechanisms are distinct, the canonical cytokine-stimulated pathway and atypical DSBinduced pathway have the same transcriptional effector - RelA(p65)/NF- $\varkappa B 1(\mathrm{p} 50)$ heterodimer and regulate similar subsets of genes (yet their activation is weaker and delayed in case of the IR-induced pathway) (Janus et al., 2018). Although ATM-mediated phosphorylation of $\mathrm{NEMO} / \mathrm{IKK} \gamma$ (at Ser85) is a key event, a multicomponent nucleoplasmic signalosome is implicated in further modification of NEMO (SUMOylation) and full activation of the IKK kinase. In addition to ATM and NEMO, this signalosome may involve several other components, including RIP1 (Huang et al., 2003; Hur et al., 2003), PIDD (Janssens et al., 2005), PARP1 (Stilmann et al., 2009), TRAF6 (Hinz et al., 2010), ELKS (Wu et al., 2010), and TIFA (Fu et al., 2018). However, not all components were observed in all experimental models, which indicated celltype specific and partly redundant functions of different signalosome components. It is generally assumed that this ATM-dependent atypical NF- $x \mathrm{~B}$ pathway represents a p53-independent type of DNA damage response (DDR). However, a few links between p53 and this particular $\mathrm{NF}-x \mathrm{~B}$ pathway exist. PIDD, a key component of ATM/ NEMO signalosome, is under transcriptional regulation by p53 (Lin et al., 2000). On the other hand, in addition to phosphorylation of $\mathrm{I} \varkappa \mathrm{B} \alpha$, an activated IKK kinase phosphorylates RelA(p65) at Ser536, which participates in regulation of nuclear translocation of $\operatorname{RelA}(\mathrm{p} 65) / \mathrm{NF}$ xB1(p50) heterodimer (Sakurai et al., 2003; Mattioli et al., 2004). Moreover, phosphorylation of RelA(p65) at Ser536 weakens its interactions with $\mathrm{I} \varkappa \mathrm{B} \alpha$, which could provide an activation mechanism independent of $\mathrm{I} x \mathrm{~B} \alpha$ phosphorylation/degradation (Sasaki et al., 2005). It is noteworthy that two proteins that are under transcriptional regulation by $\mathrm{p} 53$ could be involved in phosphorylation/dephosphorylation of RelA(p65) at Ser536: the RSK1 protein kinase (Bohuslav et al., 2004) and the WIP1 protein phosphatase (Chew et al., 2009). Therefore, the status of p53 could hypothetically affect activation of the atypical NF- $x \mathrm{~B}$ pathway induced by DNA DSB.

In this report we aimed to test this hypothesis by using three different models, and compared cell variants that either contained functional p53 or were depleted of this protein. A single high dose of IR activated ATM-dependent DDR (including activation of p53 in p53-proficient cells), which resulted in activation of $\mathrm{NF}-x \mathrm{~B}$. We used the same cell models to activate the canonical NF- $x \mathrm{~B}$ pathway upon cytokine stimulation, which did not activate ATMdependent DDR. Although some differences in the kinetics of IR-induced activation of $\mathrm{NF}-x \mathrm{~B}$ were observed among the three analyzed cell lines, no significant differences were noted between p53-proficient and p53-deficient variants. As expected, IR-induced activation of NF-

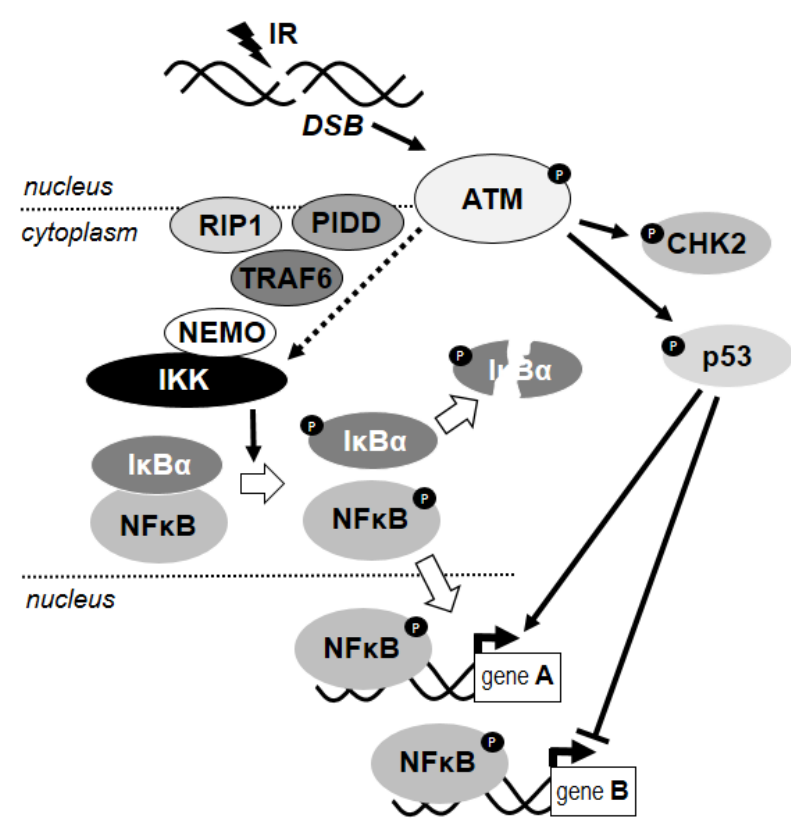

Figure 4. Schematic presentation of hypothetical influence of p53 on the IR-induced activation of the atypical NF-kB pathway and subsequent activation of NF-KB-dependent genes.

Components of the ATM-NEMO signalosome are marked as ovals with solid borders.

$x \mathrm{~B}$ was weakened and delayed when compared to the cytokine-induced activation. However, similar to IR-induced effects, though certain differences were noted among the analyzed cell lines, similar kinetics of cytokine-induced activation of $\mathrm{NF}-x \mathrm{~B}$ were observed irrespective of the p53 status. Therefore, we concluded that neither activation of the IR-induced atypical NF- $x \mathrm{~B}$ pathway nor activation of the cytokine-induced canonical $\mathrm{NF}-x \mathrm{~B}$ pathway was affected by $\mathrm{p} 53$. It is noteworthy that similar effects were observed in cells of endoderm (HCT116 and RKO) and mesoderm (U2-OS) origin, which suggests its generality. In marked contrast, we found that the presence of p53, both in the cytokine-stimulated and irradiated cells, affected expression of genes that are $\mathrm{NF}-\varkappa \mathrm{B}$ targets. This phenomenon reflected known interference between both transcription factors, since expression of many NF- $x \mathrm{~B}-$ dependent genes is directly and indirectly affected by p53 (Carrà et al., 2020; Webster \& Perkins, 1999; Huang et al., 2007; Szołtysek et al., 2018). Interestingly, we noted different patterns of p53-related effects that depended on the gene and cell type, which putatively reflected gene-specific and cell-specific mechanisms of crosstalk between both transcription factors. Nevertheless, in contrast to activation of the pathway addressed at the level of $\mathrm{I} x \mathrm{~B} \alpha$ inhibitor and NF- $x \mathrm{~B}$ effector, the downstream results of NF- $x \mathrm{~B}$ activation, i.e., the expression of target genes, are sensitive to the p53 status (which is schematically presented in Fig. 4). Therefore, one should consider that information on expression of the NF- $x \mathrm{~B}$ target genes is not sufficient and should be complemented by information on the NF$x \mathrm{~B}$ itself to draw a credible conclusion on the activity of this pathway.

\section{Acknowledgements}

The authors want to thank Dr. Patryk Janus for useful advice concerning the qRT-PCR assay. 


\section{Conflicts of Interest}

The authors declare no conflict of interests.

\section{REFERENCES}

Banin S, Moyal L, Shieh S, Taya Y, Anderson CW, Chessa L, Smorodinsky NI, Prives C, Reiss Y, Shiloh Y, Ziv Y (1998) Enhanced phosphorylation of p53 by ATM in response to DNA damage. Science 281: 1674-1677. https://doi.org/10.1126/ science.281.5383.1674.

Blagih J, Buck MD, Vousden KH (2020) p53, cancer and the immune response. J Cell Sci 133: jcs237453. https://doi.org/10.1242/ jcs.237453.

Bohuslav J, Chen LF, Kwon H, Mu Y, Greene WC (2004) p53 induces NF-kappaB activation by an IkappaB kinase-independent mechanism involving phosphorylation of $\mathrm{p} 65$ by ribosomal S6 kinase 1. J Biol Chem 279: 26115-26225. https://doi.org/10.1074/ jbc.M313509200.

Brach MA, Hass R, Sherman ML, Gunji H, Weichselbaum R, Kufe D (1991) Ionizing radiation induces expression and binding activity of the nuclear factor kappa B. J Clin Invest 88: 691-695. https://doi. org/10.1172/JCI115354.

Bunz F, Dutriaux A, Lengauer C, Waldman T, Zhou S, Brown JP, Sedivy JM, Kinzler KW, Vogelstein B (1998) Requirement for p53 and p21 to sustain G2 arrest after DNA damage. Science 282: 14971501. https://doi.org/10.1126/science.282.5393.1497.

Carrà G, Lingua MF, Maffeo B, Taulli R, Morotti A (2020) P53 vs NF- $x$ B: the role of nuclear factor-kappa B in the regulation of p53 activity and vice versa. Cell Mol Life Sci 77: 4449-4458. https://doi. org/10.1007/s00018-020-03524-9

Chew J, Biswas S, Shreeram S, Humaidi M, Wong ET, Dhillion MK, Teo H, Hazra A, Fang CC, López-Collazo E, Bulavin DV, Tergaonkar V (2009) WIP1 phosphatase is a negative regulator of NF-kappaB signalling. Nat Cell Biol 11: 659-666. https://doi. org/10.1038/ncb1873.

Dunphy G, Flannery SM, Almine JF, Connolly DJ, Paulus C, Jønsson KL, Jakobsen MR, Nevels MM, Bowie AG, Unterholzner L (2018) Non-canonical activation of the DNA sensing adaptor STING by ATM and IFI16 mediates NF- $x$ B signaling after nuclear DNA damage. Mol Cell 71: 745-760.e5. https://doi.org/10.1016/j. molcel.2018.07.034.

Fu J, Huang D, Yuan F, Xie N, Li Q, Sun X, Zhou X, Li G, Tong T, Zhang Y (2018) TRAF-interacting protein with forkhead-associated domain (TIFA) transduces DNA damage-induced activation of NF-xB. J Biol Chem 293: 7268-7280. https://doi.org/10.1074/jbc. RA117.001684.

Habraken Y, Piette J (2006) NF-kappaB activation by double-strand breaks. Biochem Pharmacol 76: 1132-1141. https://doi.org/10.1016/j. bcp.2006.07.015.

Hayden MS, Ghosh S (2012) NF- $x$ B, the first quarter-century: remarkable progress and outstanding questions. Genes Dev 26: 203 234. https://doi.org/10.1101/gad.183434.111.

Hellweg CE (2015) The Nuclear Factor $x \mathrm{~B}$ pathway: A link to the immune system in the radiation response. Cancer Lett 368: 275-289. https://doi.org/10.1016/j.canlet.2015.02.019.

Hinz M, Stilmann M, Arslan SC, Khanna KK, Dittmar G, Scheidereit C (2010) A cytoplasmic ATM-TRAF6-cIAP1 module links nuclear DNA damage signaling to ubiquitin-mediated NF- $x \mathrm{~B}$ activation. Mol Cell 40: 63-74. https://doi.org/10.1016/j.molcel.2010.09.008.

Hoesel B, Schmid JA (2013) The complexity of NF-xB signaling in inflammation and cancer. Mol Cancer 12: 86. https://doi. org/10.1186/1476-4598-12-86.

Huang TT, Wuerzberger-Davis SM, Wu ZH, Miyamoto S (2003) Sequential modification of NEMO/IKKgamma by SUMO-1 and ubiquitin mediates NF-kappaB activation by genotoxic stress. Cell 115: 565-576. https://doi.org/10.1016/s0092-8674(03)00895-x.

Huang WC, Ju TK, Hung MC, Chen CC (2007) Phosphorylation of CBP by IKKalpha promotes cell growth by switching the binding preference of CBP from p53 to NF-kappaB. Mol Cell 26: 75-87. https://doi.org/10.1016/j.molcel.2007.02.019

Hur GM, Lewis J, Yang Q, Lin Y, Nakano H, Nedospasov S, Liu ZG (2003) The death domain kinase RIP has an essential role in DNA damage-induced NF-kappa B activation. Genes Dev 17: 873-882. https://doi.org/10.1101/gad.1062403.

Janssens S, Tinel A, Lippens S, Tschopp J (2005) PIDD mediates NFkappaB activation in response to DNA damage. Cell 123: 10791092. https://doi.org/10.1016/i.cell.2005.09.036.

Janssens S, Tschopp J (2006) Signals from within: the DNA-damageinduced NF-kappaB response. Cell Death Differ 13: 773-784. https:// doi.org/10.1038/sj.cdd.4401843.

Janus P, Szołtysek K, Zając G, Stokowy T, Walaszczyk A, Widłak W, Wojtaś B, Gielniewski B, Iwanaszko M, Braun R, Cockell S, Perkins
ND, Kimmel M, Widlak P (2018) Pro-inflammatory cytokine and high doses of ionizing radiation have similar effects on the expression of NF-kappaB-dependent genes. Cell Signal 46: 23-31. https://doi.org/10.1016/j.cellsig.2018.02.011.

Kessis TD, Slebos RJ, Nelson WG, Kastan MB, Punkett BS, Han SM, Lorincz AT, Hedrick L, Cho KR (1993) Human papillomavirus 16 E6 expression disrupts the p53-mediated cellular response to DNA damage. Proc Natl Acad Sci USA 90: 3988-3992. https://doi. org/10.1073/pnas.90.9.3988

Kriete A, Mayo KL (2009) Atypical pathways of NF-kappaB activation and aging. Exp Gerontol 44: 250-255. https://doi.org/10.1016/j. exger.2008.12.005.

Levine AJ, Oren M (2009) The first 30 years of p53: growing ever more complex. Nat Rev Cancer 9: 749-758. https://doi.org/ $10.1038 / \mathrm{nrc} 2723$.

Li N, Karin M (1998) Ionizing radiation and short wavelength UV activate NF-kappaB through two distinct mechanisms. Proc Natl Acad Sci USA 95: 13012-13017. https://doi.org/10.1073/ pnas.95.22.13012

Lin Y, Ma W, Benchimol S (2000) Pidd, a new death-domaincontaining protein, is induced by $\mathrm{p} 53$ and promotes apoptosis. Nat Genet 26: 122-127. https://doi.org/10.1038/79102.

Mattioli I, Sebald A, Bucher C, Charles RP, Nakano H, Doi T, Kracht M, Schmitz ML (2004) Transient and selective NF-kappa B p65 serine 536 phosphorylation induced by $\mathrm{T}$ cell costimulation is mediated by I kappa B kinase beta and controls the kinetics of p65 nuclear import. J Immunol 172: 6336-6344. https://doi.org/10.4049/ jimmunol.172.10.6336.

Perkins ND (2012) The diverse and complex roles of NF- $x \mathrm{~B}$ subunits in cancer. Nat Rev Cancer 12: 121-132. https://doi.org/10.1038/ nrc3204.

Sakurai H, Suzuki S, Kawasaki N, Nakano H, Okazaki T, Chino A, Doi T, Saiki I (2003) Tumor necrosis factor-alpha-induced IKK phosphorylation of NF-kappaB p 65 on serine 536 is mediated through the TRAF2, TRAF5, and TAK1 signaling pathway. $J$ Biol Chem 278: 36916-36923. https://doi.org/10.1074/jbc.M301598200.

Sasaki CY, Barberi TJ, Ghosh P, Longo DL (2005) Phosphorylation of RelA/p65 on serine 536 defines an $\mathrm{I} x \mathrm{~B} \alpha$-independent NF- $x \mathrm{~B}$ pathway. J Biol Chem 280: 34538-34547. https://doi.org/10.1074/ jbc.M504943200.

Stilmann M, Hinz M, Arslan SC, Zimmer A, Schreiber V, Scheidereit C (2009) A nuclear poly(ADP-ribose)-dependent signalosome confers DNA damage-induced IkappaB kinase activation. Mol Cell 36: 365-378. https://doi.org/10.1016/j.molcel.2009.09.032.

Sun SC (2011) Non-canonical NF- $x$ B signaling pathway. Cell Res 21: 71-85. https://doi.org/10.1038/cr.2010.177.

Szołtysek K, Janus P, Zając G, Stokowy T, Walaszczyk A, Widłak W, Wojtaś B, Gielniewski B, Cockell S, Perkins ND, Kimmel M, Widlak P (2018) RRAD, IL4I1, CDKN1A, and SERPINE1 genes are potentially co-regulated by $\mathrm{NF}-x \mathrm{~B}$ and $\mathrm{p} 53$ transcription factors in cells exposed to high doses of ionizing radiation. BMC Genomics 19: 813. https://doi.org/10.1186/s12864-018-5211-y.

Taniguchi K, Karin M (2018) NF-xB, inflammation, immunity and cancer: coming of age. Nat Rev Immunol 18: 309-324. https://doi. org/ 10.1038/nri.2017.142.

Tergaonkar V, Pando M, Vafa O, Wahl G, Verma I (2002) p53 stabilization is decreased upon NFkappaB activation: a role for NFkappaB in acquisition of resistance to chemotherapy. Cancer Cell 1: 493-503. https://doi.org/10.1016/s1535-6108(02)00068-5.

Vallabhapurapu S, Karin M (2009) Regulation and function of NF-kappaB transcription factors in the immune system. Annu Rev Immunol 27: 693-733. https://doi.org/10.1146/annurev. immunol.021908.132641.

Webster GA, Perkins ND (1999) Transcriptional cross talk between NF-kappaB and p53. Mol Cell Biol 19: 3485-3495. https://doi.org/ 10.1128/MCB.19.5.3485.

Wu ZH, Miyamoto S (2007) Many faces of NF-kappaB signaling induced by genotoxic stress. J Mol Med Berl Ger 85: 1187-1202. https://doi.org/10.1007/s00109-007-0227-9.

Wu ZH, Shi Y, Tibbetts RS, Mivamoto S (2006) Molecular linkage between the kinase ATM and NF-kappaB signaling in response to genotoxic stimuli. Science 311: 1141-1146. https://doi.org/10.1126/ science. 1121513.

Wu ZH, Wong ET, Shi Y, Niu J, Chen Z, Miyamoto S, Tergaonkar V (2010) ATM- and NEMO-dependent ELKS ubiquitination coordinates TAK1-mediated IKK activation in response to genotoxic stress. Mol. Cell 40: 75-86. https://doi.org/10.1016/j. molcel.2010.09.010.

Zajkowicz A, Gdowicz-Kłosok A, Krześniak M, Ścieglińska D, Rusin M (2015) Actinomycin D and nutlin-3a synergistically promote phosphorylation of p53 on serine 46 in cancer cell lines of different origin. Cell Signal 27: 1677-1687. https://doi.org/10.1016/j. cellsig.2015.05.005 